\title{
MODERN EPIDEMIOLOGICAL ASPECTS OF THE PROBLEM OF UROGENITAL MYCOPLASMIS AMONG THE FEMALE POPULATION OF UKRAINE
}

DOI: $10.36740 /$ WLek202103218

\author{
Liudmyla I. Haliienko, Viktoriia B. Zamkevych, Oleksandr V. Zholobko, Nataliia M. Mykytenko, Nataliia V. Velikaia \\ BOGOMOLETS NATIONAL MEDICAL UNIVERSITY, KYIV, UKRAINE
}

\begin{abstract}
The aim: To study and analyze the dynamics, age, and regional characteristics of the incidence of urogenital mycoplasmosis in Ukraine during 2014-2019 and to substantiate medical and organizational approaches to improving the prevention of urogenital mycoplasmosis among women.

Materials and methods: To study the dynamics, age, and regional characteristics of the prevalence and incidence of urogenital mycoplasmosis in women, reference and statistical materials of the State Statistics Service of Ukraine, reference materials and data from reporting forms No. 9, 34, 35 of the Center for Medical Statistics for 2014-2019 were used. Results: The current trends in the dynamics of the incidence of urogenital mycoplasmosis among female population in Ukraine during 2015-2019 are determined, its age features are established, the regional distribution of administrative territories of Ukraine according to the incidence of urogenital mycoplasmosis is substantiated, medical and organizational approaches to improving menopause among women are substantiated.

Conclusions: The results of the study showed that although urogenital mycoplasmosis is most often diagnosed among women of childbearing age, the risk of infection exists for women of all ages, which indicates the urgency of providing effective measures to prevent it.A wide range of regional indicators of incidence of urogenital mycoplasmosis in women was established: from 0.9 per 100 thousand female population in the Zakarpattia region to 230.9 per 100 thousand in Kharkiv region, with in excess of the average Ukrainian indicator in a number of oblasts by1.8-3.2 times. There is a tendency towards redistribution during 2010-2018 of the age structure of patients with urogenital mycoplasmosis: against the background of a slight decrease in the proportion of age groups from 0 to $14,15-19,20-29$ years there is an increase in the proportion of other age groups, but the first rank place, as in previous years, is retained by the age group of $20-29$ years: $48.4 \%$ in $2010,39.1 \%$ in 2018 ). A statistically reliable correlation connection between age and the level of incidence of urogenital mycoplasmosis among women is not revealed.
\end{abstract}

KEY WORDS: urogenital mycoplasmosis, female population, prevention

Wiad Lek. 2021;74(3 p.II):665-668

\section{INTRODUCTION}

According to the World Health Organization, more than 1 million cases of sexually transmitted infections (STIs) are registered in the world every day. It is diagnosed every year 376 million cases of infection with one of the most common STIs: chlamydia, gonorrhea, trichomoniasis, and syphilis [1]. In Ukraine, about 400,000 new cases of STIs are diagnosed annually. These diseases, in particular, syphilis, chlamydia, gonorrhea, trichomoniasis, urogenital mycoplasmosis, and otherSTIs, adversely affect reproductive health, leading to infertility, miscarriage, stillbirth, and more. However, official statistics, both in Ukraine and in other countries, do not reflect the real situation of the STIburden, which remains a persistent health threat [2-4]. The strategic priorities of the $\mathrm{UN}, \mathrm{WHO}$, and other international organizations are to implement effective measures to combat the spread of STIs to address reproductive health problems, including improving their prevention, optimizing the quality of national and global surveillance, ensuring accessibility, quality and effectiveness medical care to these categories of patients [5].

\section{THE AIM}

The aim of the work is to study and analyze the dynamics, age, and regional characteristics of the incidence of urogenital mycoplasmosis among women in Ukraine during 2014-2019 and to substantiate medical and organizational approaches to improving the prevention of urogenital mycoplasmosis among women.

\section{MATERIALS AND METHODS}

To study the dynamics, age, and regional characteristics of the prevalence and incidence of urogenital mycoplasmosis in women, reference and statistical materials of the State Statistics Service of Ukraine, reference materials and data from reporting forms No. 9, 34, 35 of the Center for Medical Statistics for 2014-2019 were used (22 units). Descriptive statistics methods were used for statistical processing and analysis of the obtained information [6-13]. 

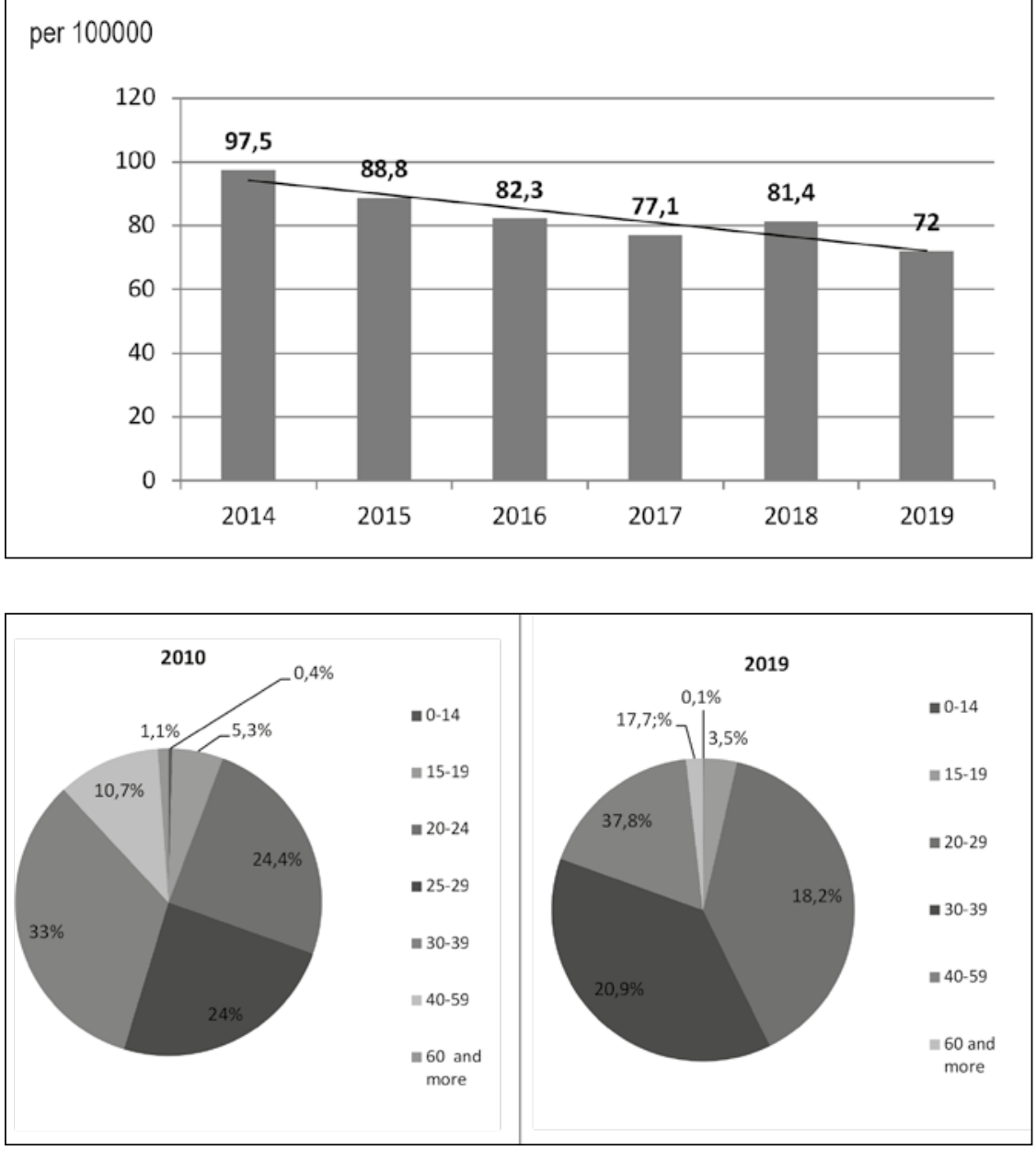

Fig. 1. Dynamics of the incidence of urogenital mycoplasmosis of the female population of Ukraine during 2014-2019 (per 100000).

Fig. 2. The age structure of women with urogenital mycoplasmosis diagnosed for the first time in their life $(2010,2019), \%$.

\section{RESULTS}

The analysis showed that despite the tendency to reduce the incidence of women in the entire spectrum of STIs, the most common diseases among women are trichomoniasis and urogenital mycoplasmosis with incidence rates in 2019-123.7 and 72.0 per 100 thousand women respectively.

It is established that during 2014-2019 in Ukraine there was a reduction in the incidence of urogenital mycoplasmosis in women by $16.5 \%$ (Fig. 1 ). There was a slower rate of reduction in the incidence of urogenital mycoplasmosis in women compared with trichomoniasis and other STIs.

The structural distribution of women with newly diagnosed urogenital mycoplasmosis according to 2018, represented by age groups: 0 - 14 years $-0.1 \pm 0.02 \% ; 15$ - 19 years $3.5 \pm 0.14 \% ; 20-29$ years $-39.1 \pm 0.38 \% ; 30-39$ years $-37.8 \pm$ $0.38 \% ; 40-59-17.7 \pm 0.3 \% ; 60$ and older $-1.8 \pm 0.1 \%$, indicates a predominance of patients aged 20-29 years.

Comparative analysis of the age distribution of women with newly diagnosed urogenital mycoplasmosis according to 2010 and 2019 revealed a tendency to a certain redistribution in the age structure of patients: against a slight reduction in the proportion of age groups from 0 to 14 years; $15-19$ p; 20-29, an increase in the share of other age groups was recorded, with the preservation of the first ranking place of the age group $20-29$ (48.4\% in $2010,39.1 \%$ in 2018) (Fig. 2).
Further study of the levels of primary morbidity of women of different ages for urogenital mycoplasmosis by correlation analysis revealed the presence of an inverse, weak, statistically unlikely correlation between the age of patients and the incidence of urogenital mycoplasmosis $(\rho=-0.29, \mathrm{p}>0.05)$.

To determine the possible impact of age on the incidence of the female population on urogenital mycoplasmosis, we evaluated the actual indicators of incidence of urogenital mycoplasmosis in 2010 and 2018 and age-standardized indicators. The analysis allowed us to conclude that there is no influence of age on the incidence of women with urogenital mycoplasmosis.

Official statistics show that the vast majority of women are first diagnosed with urogenital mycoplasmosis diagnosed during preventive medical examinations and other types of dispensary work. These indicators are characterized by significant regional fluctuations - from $4.7 \%$ in the Zakarpattia region to $78.1 \%$ in Cherkasy, but their highest levels are in Cherkasy (78.1\%), Kharkiv (74.4\%), Zhytomyr (71.4\%), and Donetsk (64.5) oblasts, which illustrates the high efficiency of preventive examinations.

Analysis of regional indicators of women's incidence of urogenital mycoplasmosis revealed a wide range at the regional level: from 0.9 per 100 thousand female popula- 


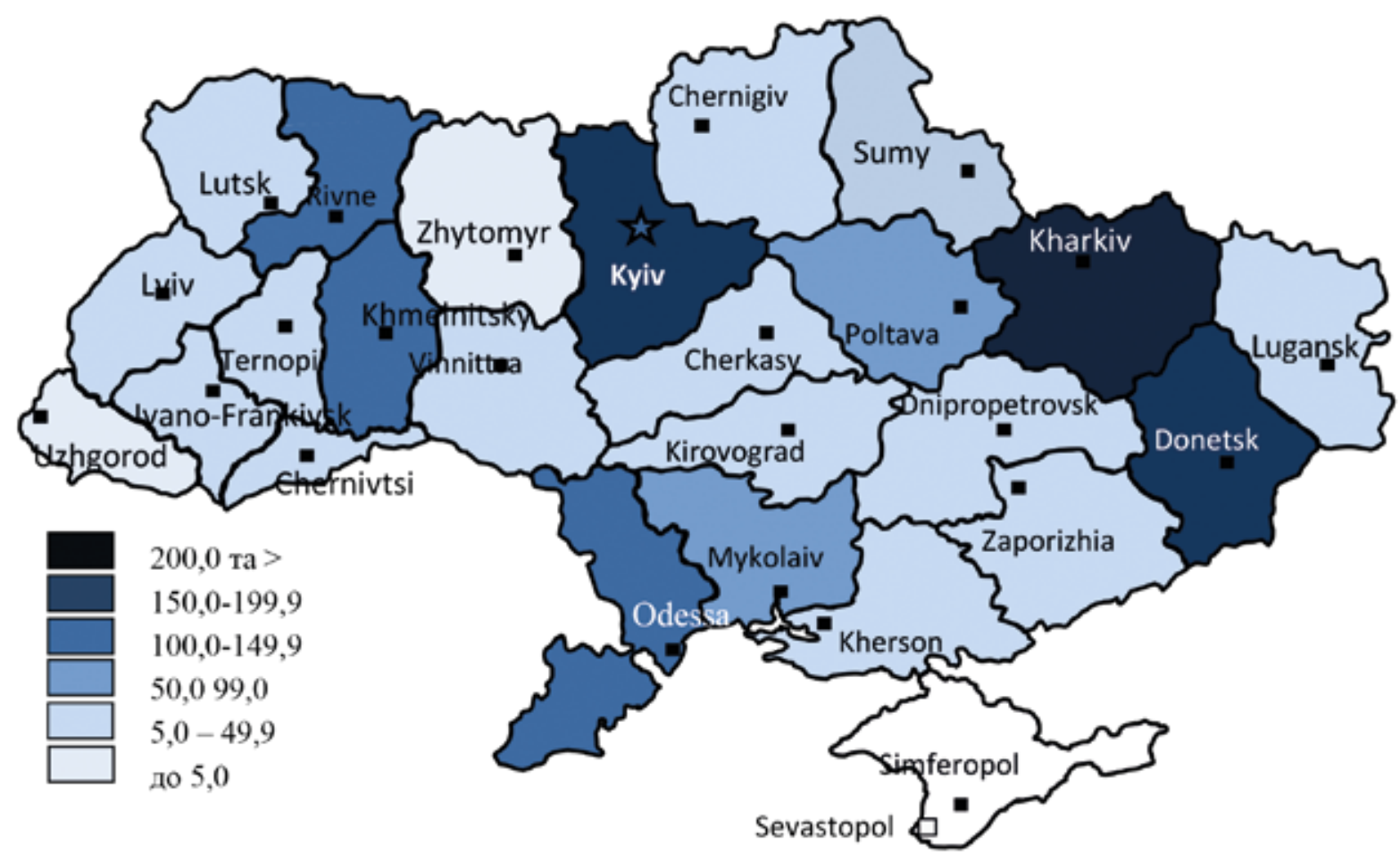

Fig. 3. Distribution of administrative territories of Ukraine by indicators of incidence for urogenital mononucleosis of the female population of Ukraine in 2019 (per 100000)

tion in the Zakarpattia region to 230.9 per 100 thousand female population in Kharkiv. It is established that in some oblasts, in particular Rivne, Khmelnytskyi, Kyiv, Kyiv, and Donetsk oblasts, the incidence of urogenital mycoplasmosis is 1.8-2.5 times higher than the average Ukrainian rate (72.0 per 100,000), in Kharkiv oblast this difference is 3.2 times (Fig. 3).

\section{DISCUSSION}

The study testified to the urgency of the problem of the prevalence of urogenital mycoplasmosis among the female population of Ukraine and the need to provide effective measures to prevent it. It has been found that women of all ages are at risk, but it is most common in women of childbearing potential, which has a negative effect on their reproductive health. Therefore, it is necessary to provide measures to prevent this disease, as well as other STIs.

In our opinion, the effective prevention of urogenital mycoplasmosis amomg population, as well as other STIs, needs a systemic solution within the relevant national / regional program/plan to preserve and promote reproductive health.

This will provide an integrated approach and intersectoral solution to the problem of prevention with the participation of public authorities and local governments, all sectors, and strata of society. It is extremely important to introduce effective epidemiological surveillance and monitoring, to ensure complete accounting of STIs in health care institutions of various forms of ownership, to strengthen the preventive focus of health care, to increase the effectiveness of health education and sex education. An important task is to improve the availability and quality of the entire range of preventive, diagnostic, and treatment services for the population in order to improve reproductive health.

\section{CONCLUSIONS}

The results of the study showed that although urogenital mycoplasmosis is most often diagnosed among women of childbearing age, the risk of infection exists for women of all ages, which indicates the urgency of providing effective measures to prevent it.

A wide range of regional indicators of incidence of urogenital mycoplasmosis in women was established: from 0.9 per 100 thousand female population in the Zakarpattia region to 230.9 per 100 thousand in Kharkiv region, with in excess of the average Ukrainian indicator in a number of oblasts by1.8-3.2 times.

There is a tendency towards redistribution during 20102018 of the age structure of patients with urogenital mycoplasmosis: against the background of a slight decrease in the proportion of age groups from 0 to 14, 15-19, 20-29 years there is an increase in the proportion of other age groups, but the first rank place, as in previous years, is retained by the age group of $20-29$ years: $48.4 \%$ in 2010 , $39.1 \%$ in 2018). A statistically reliable correlation connec- 
tion between age and the level of incidence of urogenital mycoplasmosis among women is not revealed.

The obtained results indicate the need for further study of this problem, in particular, risk assessment of urogenital mycoplasmosis at the regional level, development of effective prevention measures, improving the availability and quality of medical care accpording the modern standards.

Effective prevention of urogenital mycoplasmosis, like other STIs, requires an integrated solution, a systemic, intersectoral approach within the framework of an appropriate national / regional program/plan for the preservation and promotion of reproductive health.

Prospects for further research will consist in studying the regional characteristics of the incidence of urogenital mycoplasmosis in women, assessing their quality of life, improving the availability and quality of medical care.

\section{REFERENCES}

1. Selected practice recommendations for contraceptive use. Third edition 2016. Geneva:WH0; 2016, 66 p.

2. Vautrin H., Senn N., Cohidon C. Primary prevention of sexually transmitted infections in Switzerland: practices of family physicians and their determinants - a national cross-sectional survey. BMJ. 2020; 10(9): e032950. doi: 10.1136/bmjopen-2019-032950.

3. Mavrov H. I., Shcherbakova Y. V., Osinska T. V. Novitni metody strymuvannya infektsiy, shcho peredayut'sya statevym shlyakhom [Novel methods of containment of sexually transmitted infections]. Infection Diseases. 2019;1:4-13. doi:10.11603/1681-2727.2019.1.9933 (in Ukrainian).

4. Komar 0.M.,Pidlisna,I.V. Analiz pokaznykivnaybil'sh rozpovsyudzhenykh zakhvoryuvan', shcho peredayut'sya statevym shlyakhom, u Vinnyts'kiy oblasti [Analysis of the indicators of the most distributed sexually transmitted diseases in Vinnytsia region]. Bulletin of Social Hygiene and Health Protection Organization of Ukraine. 2019; 2:5-9. doi:10.11603/1681-2786.2019.2.10474. (in Ukrainian).

5. HRP annual report 2018. Geneva:WH0; 2019, 45 p.

6. Indicators of treatment and prevention of patients with skin and sexually transmitted diseases in Ukraine in 2018/K., Center for Medical Statistics of the Ministry of Health of Ukraine. 2019.

7. The state of health of the female population in 2018. K., Center for Medical Statistics of the Ministry of Health of Ukraine. 2019. URL: http:// medstat.gov.ua/ukr/MMXIX.html.

8. Statistical data of the system of the Ministry of Health of Ukraine for 2014-2019. K., Center for Medical Statistics of the Ministry of Health of Ukraine. URL: http://medstat.gov.ua /ukr/statdan. html.
9. Zhuk I.M. Statistical Yearbook of Ukraine for 2014. Kyiv, State Statistics Service of Ukraine. 2015, $586 \mathrm{p}$.

10. Werner I.E. Statistical Yearbook of Ukraine for 2016. Kyiv, State Statistics Service of Ukraine. 2017. $611 \mathrm{p}$.

11. Werner I.E. Statistical Yearbook of Ukraine for 2017. Kyiv, State Statistics Service of Ukraine. 2018.URL: http://www.ukrstat.gov.ua/druk/ publicat/kat_u/2018/zb/11/zb_seu2017_e.

12. Werner I.E. Statistical Yearbook of Ukraine for 2018. Kyiv, State Statistics Service of Ukraine. 2019. 482 p. URL:http://www.ukrstat.gov.ua/druk/ publicat/kat_u/2019/zb/11/zb_yearbook_2018 e.

13. Werner I.E. Statistical Yearbook of Ukraine for 2019. Kyiv, State Statistics Service of Ukraine. 2020. 465 p.

The article was performed in framework of research "Medico-social substantiation of optimization of the organization of medical care in the conditions of development of the public health system", (2020-2022, № state registration 0120U100807).

\section{ORCID and contributionship:}

Liudmyla I. Haliienko: 0000-0003-3728-9445 A,B,F

Viktoriia B. Zamkevych: 0000-0003-2735-838X C,D,F

Oleksandr V. Zholobko: 0000-0002-8016-703 ${ }^{E, F}$

Nataliia M. Mykytenko: ${ }^{A, C}$

Nataliia V. Velikaia: 0000-0003-3497-7584 ${ }^{F}$

\section{Conflict of interest:}

The Authors declare no conflict of interest.

\section{CORRESPONDING AUTHOR \\ Liudmyla I. Haliienko}

Bogomolets National Medical University

13 Taras Shevchenko Boulevard, 01601 Kyiv, Ukraine

tel: +380674024857

e-mail:mila_galiyenko@ukr.net

Received: 10.12 .2020

Accepted: 02.03.2021

A - Work concept and design, B - Data collection and analysis, C - Responsibility for statistical analysis,

D-Writing the article, E-Critical review, $\mathbf{F}$ - Final approval of the article 